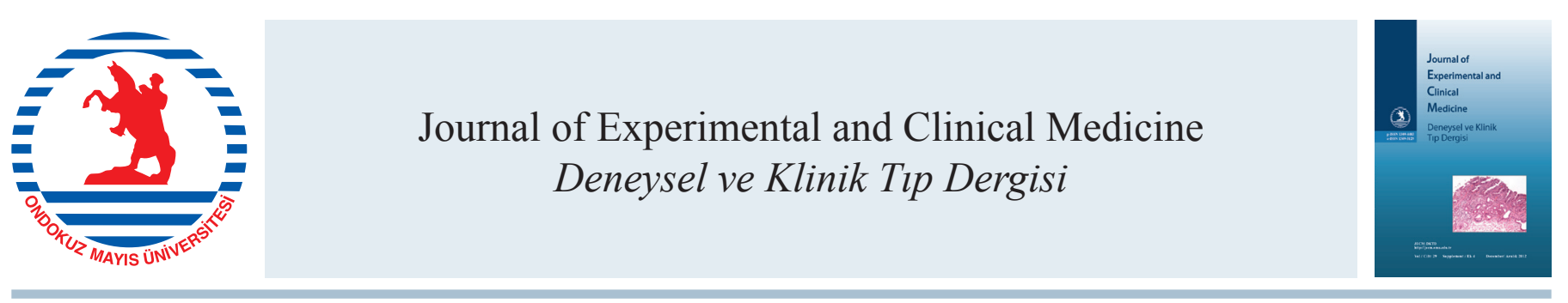

Derleme / Review

doi: $10.5835 /$ jecm.omu.29.s4.008

\title{
Özofagus kanseri cerrahisinde komplikasyonlar ve tedavisi
}

\section{Complications of esophageal cancer surgery and treatment}

\author{
Murat Özkan*, İlker Ökten \\ Ankara Üniversitesi Tıp Fakültesi, Göğ̈̈s Cerrahisi Anabilim Dalı, Ankara
}

MAKALE BILGILERİ ÖZET

\section{Makale geçmişi}

Geliş tarihi : :01/02/2012

Kabul tarihi $\quad: 27 / 09 / 2012$

\section{* Yazışma Adresi:}

Murat Özkan

Ankara Üniversitesi, Tıp Fakültesi,

Göğüs Cerrahisi Anabilim Dalı,

Ankara

e-posta:muratoz73@hotmail.com

\author{
Anahtar Kelimeler: \\ Özofagus kanseri \\ Rezeksiyon \\ Özofajektomi \\ Anastomoz \\ Komplikasyon \\ Morbidite
}

\section{Keywords:}

Esophageal cancer

Resection

Esophagectomy

Anastomosis

Complication

Morbidity
Özofagus kanserinin cerrahi tedavisi ile ilişkili morbidite oranı hasta seçimi, cerrahi teknik ve perioperatif yaklaşımdaki iyileşme ve gelişmeler nedeniyle son yıllarda belirgin derecede düşmüş olmasına rağmen hala yüksektir. Solunum yetmezliği, sepsis, anastomoz kaçağı, özofageal striktür, fistül, reflü, obstrüksiyon, kanama, şilotoraks, pnömotoraks, pankreatit ve dalak yaralanması özofagus kanseri cerrahisinde karşılaşılan başlıca komplikasyonlardır. Solunum fizyoterapisi ve ağrı kontrolü pulmoner komplikasyonların önlenmesinde anahtar iki yaklaşımdır. Anastomoz kaçağı yüksek morbidite ve mortalite oranı ile önemli bir komplikasyondur. Özofageal striktür postoperatif ilk 3 ayda 30-50\% olguda görülür. Çoğunlukla tekrar eden dilatasyonlarla tedavi edilir. Hava yolları ve özofagus arasında fistül gelişimi tedavi edilmez ise mortalitenin kaçınılmaz olduğu bir komplikasyondur. Yüksek morbidite ve mortalite oranlarına rağmen özofagus kanserinde cerrahi tedavi esas tedavi yöntemidir.

J. Exp. Clin. Med., 2012; 29:S237-S242

\begin{abstract}
Morbidity rate associated with surgical treatment of esophageal cancer is still high, although it is significantly decreased in recent years according to improvements and developments in patient selection, surgical technique and perioperative approach. Respiratory failure, sepsis, anastomotic leakage, esophageal stricture, fistula, reflux, obstruction, bleeding, chylothorax, pneumothorax, pancreatitis and splenic injuries are major complications of esophageal cancer surgery. Respiratory physiotherapy and pain control are two key approaches in prevention of pulmonary complications. Anastomotic leakage is a significant complication with high morbidity and mortality rate. Esophageal stricture occurs in $30-50 \%$ of cases in the first three months, postoperatively. It is often treated with repeated dilatations. Mortality is inevitable for the development of fistula between airways and the trachea, if it is left untreated. Despite its high morbidity and mortality rates, surgical treatment is the main treatment modality of esophageal cancer. J. Exp. Clin. Med., 2012; 29: S237-S242
\end{abstract}

\section{Giriş}

Özofagus kanserinin cerrahi tedavisi sonrası görülen komplikasyonlar ile ilgili şimdiye kadar yapılmış hemen hemen bütün büyük çalışmalarda solunum yetmezliği ve sepsis en önemli iki mortalite nedeni olarak belirtilmiştir (Akiyama ve Hiyama, 1974). Muller ve arkadaşlarının yaptığı, bir çalışmada postoperatif mortalite oranı \% 50 olarak belirtilmiştir. Bu oran transhiyatal girişim uygulanan hastalar için \% 11 olarak vurgulanmıştır (Muller ve ark., 1990). Özofagus kanserinin cerrahi tedavisi sonrası görülen komplikasyonlar şunlardır:

\section{Pulmoner komplikasyonlar}

Özofagus rezeksiyonundan sonra solunum yetmezliği \% 40 oranında görülür (Postlethwait, 1983; Shahian ve ark., 1986). Pulmoner komplikasyonları azaltmanın en önemli yolu preoperatif pulmoner fizyoterapidir. Uygun postoperatif analjezi, özellikle de epidural analjezi postoperatif pulmoner komplikasyonların önlenmesinde önemlidir. Özofagus rezeksiyonundan sonra en tehlikeli komplikasyonlardan birisi de trakeobronşial sistemle özofagus veya özofagusun yerine konan mide veya bağırsak arasındaki fistüldür (Kron ve ark., 1989). 


\section{Anastomoz kaçağı}

Özofagus anastomoz kaçağı en sık karşılaşılan ve yüksek morbidite ve mortalite taşıyan bir komplikasyondur. Özofajektomi sonrası anastomoz kaçak oranı \% 25'lere kadar değişen oranlarda görülür. Birçok faktör anastomoz kaçağ i için sorumlu tutulmuştur.

Özofagusun serozasının olmaması, kas dokusunun longitudinal ve frajil olması anastomoz kaçağının en önemli nedenlerindendir. Bunun dışında özofagusun kanlanmasının perforan arterler ile olması ve diseksiyonlarda bu arterlerin genellikle bağlanması nedeniyle rezeksiyon sonrası kalan özofagusta beslenme problemi ve buna bağlı anastomoz kaçağ1 görülebilir. Özofagusun diseksiyonu sırasında kanamanın çok olması özofagus kanlanmasının iyi olduğuna, kanamanın az olması ise özofagus kanlanmasının kötü olduğuna, bu da postoperatif dönemde beslenme problemi yaşanabileceğine işaret eder.

İntratorasik mediastinal basınç özellikle gıdaların geçişi sırasında atmosfer basıncına göre negatiftir. Ayrıca anastomozun maruz kaldığı sindirim enzimleri, safra asitleri, tükrükteki hidroklorik asit $(\mathrm{HCl})$, mide içeriği ve bilier reflü, anaerobik oral flora anastomoz kaçağının oluşmasında etkendir.

Preoperatif düşük albumin seviyesi ve kadın cinsiyet kaçak riskini artırır. Hepatik siroz, böbrek yetmezliği, Diabetes mellitus (DM), kalp hastalığı, pulmoner yetmezlik genel olarak cerrahiyi etkileyen faktörlerdendir. İntraoperatif faktör olarak fazla kan kaybı anastomoz kaçağından sorumlu tutulmuştur. Gecikmiş gastrik boşalma kaçak riskini artırır (Orringer ve ark., 2000). Devamlı dikiş tek tek sütüre göre daha risklidir. Cerrahi tecrübesi fazla olmayan ellerde manuel dikişte risk stapler ile dikişten daha fazladır. Çift kat sütürlerde risk azalır. Kolon interpoze edilmişse kaçak daha fazla görülür. Retrosternal yoldan rekonstrüksiyon posterior mediastinal yola göre daha risklidir. Boyunda anastomoz toraks içi anastomoza göre kaçak yönünden daha az risklidir.

Genelde cerrahlar postoperatif 5-7. günlerde kontrol amaçlı özofagografi çektirirler. Biz ise kaçak kontrolü için hastalarımıza rutin olarak metilen mavisi ile boyanmış su içiriyoruz. Birçok kaçak klinik şüpheyle fark edilir. Özofagus rezeksiyonu sonrası 48 saatten uzun süren 38 derece üzeri ateş görüldüğünde aksi ispat edilinceye kadar kaçak düşünülmelidir (Orringer ve ark., 2000). İntratorasik kaçaklar genellikle taşikardi, ateş ve sistemik inflamatuar cevap sendromu (SIRS) ile ortaya çıkar. Lökositoz her zaman olmayabilir. Nadiren anastomoz kaçağı drenden gözlenir. Genellikle belirgin seröz drenaj olması kaçak olmadığını göstermeyebilir. İnce bağırsak kaçaklarında çok ciddi lökositoz olur. Eğer ciddi olarak intratorasik kaçaktan şüpheleniliyor fakat özofagografi normalse BT çektirilir veya endoskopi yapılır (Orringer ve ark., 2000). Servikal kaçaklarda boyunda yumuşak doku enfeksiyonu, eritem ve drenaj olur. Eğer kaçaktan şüpheleniliyorsa lokal anestezikle boyun açılır ve kaçağın drene olması sağlanır. Ayrıca metilen mavisi ile kaçak olan bölge saptanmaya çalışılır. Cilt altı amfizemi kaçak için bir belirtidir.

Eğer servikal anastomozlarda kaçak oluşursa insizyon hasta yatağında tümüyle açılabilir. Kaçak boyutu hastaya su içirilerek yara kenarından kaçan suyun miktarına göre tayin edilir (Orringer ve ark., 2000). Genellikle yarayı açtıktan birkaç gün sonra drenaj belirgin olarak azalır ve hasta oral alabilir. Servikal fistül drenajından sonra ilk hafta Maloney dilatörleri kullanılabilir. Yüzde doksansekiz oranında anastomoz kaçakları küçüktür ve açık drenaja yanıt verir. Küçük bir kısmında ciddi komplikasyonlar gelişir. Bunlar anastomozun iptal edilmesine sebebiyet verebilecek özellikte gastrik nekroz, vertebral korpus osteomyeliti, epidural apse ve parapleji, pulmoner mikroapseler ve trakeoözofagogastrik fistüldür (Iannettoni ve ark., 1995).

Hastada ateş, göğüs ağrısı, taşikardi, nefes darlığı, takipne, hipotansiyon, şok bulguları ile kendini gösteren mediastinit tablosu gelişebilir. Akciğer grafisinde hidrotoraks ve/veya pnömotoraks tespit edilebilir. Kontrastlı çalışma ile kaçak mutlaka gösterilmelidir. Genellikle $<1 \mathrm{~cm}$ kaçaklar asemptomatiktir, hastada tedavi gerektirmez. Ancak çoğu olguda anastomoz kaçağı reeksplorasyon, göğüs ve mediyasten irrigasyonu, fistül onarımı ve gögüs tüpü drenajını gerektirir. Lokalize anastomoz kaçağı komşu dokular normalse direkt sütürasyonla onarılabilir. Anterior mediastinal yağ doku, interkostal kas flebi, plevra veya omentumla desteklenme uygulanmalıdır. Nazogastrik tüple mide dekompresyonu, nutrisyonel destek için jejunostomi tüpü ve uygun antibiyotik tedavisi ile tedavi tamamlanır. Eğer anastomoz bozulursa özofagoplevrokutanöz fistül oluşturulur. Fistüle komşu geniş bir drenaj tüpü yerleştirmek için kosta rezeksiyonu gerekebilir. Böylece özofagus kaçağı gögüs dışına rahatça drene edilebilir. Eğer reeksplorasyonda ciddi lokal nekroz saptanırsa anastomoz iptal edilerek mide tekrar karına yerleştirilir. Sadece distal özofagus rezeke edilmelidir, proksimal uç dikilmemelidir ve enfekte mediyastende bırakılmamalıdır. Eş zamanlı olarak lateral servikal özofagostomi uygulanır. Kalan intratorasik özofagus segmentinin rekonstrüksiyonu ciddi bir cerrahi problem oluşturur. En iyi alternatif özofagusu sirkumferansiyel olarak torasik insizyon yoluyla boyuna mobilize etmektir. Özofagusun submukozal kollateral dolaşımı mükemmeldir ve en az bir inferior tiroid arter sağlamsa torasik özofagus canlı kalabilir. Bu nedenle torasik özofagus boyun insizyonundan çıkarıldıktan sonra geri kalan canlı özofagus standart servikal özofagostomi için kullanılabilir. Daha iyisi daha sonra rekonstrüksiyon oluşturmak için maksimum uzunlukta özofagusun korunmasıdır. Ön göğüs duvarına yerleştirilen özofagostomi stomasına standart servikal özofagostomiye göre hasta tarafından daha iyi adapte olunur. Jejunostomi mutlaka gereklidir. Eğer özofagus replasmanı kolon veya jejenumdan yapılmışsa ve kaçak sonrası nekroz gözlenmişse yapılacak olan canlı olmayan kısmı çıkarmak ve beslenme tüpü yerleştirmektir. Eğer hasta mediastinal sepsisten ölmezse sonra rekonstrüksiyon yapılabilir.

\section{Özofageal striktür}

Servikal anastomoz kaçakları iyileşme sırasında \% 50 oranında anastomotik striktür ile sonuçlanır ve hastada yutma güçlüğüne neden olur. \% 30-50 olguda ilk 3 ayda görülür. Taburcu olduktan birkaç hafta sonra gelişen disfaji tipiktir. Anastomozda skar dokusu kontraktür oluşturdukça şikâyetler progresyon gösterir. Muller ve arkadaşları (1990), özofagus kanseri nedeniyle özofajektomi uygulanan 46692 hastada yaptıkları çalışmalarında, tek katmanlı veya iki katmanlı anastomoz uygulanan hastalar arasında striktür yönünden fark bulamamışlardır. Anastomozu manuel yapılan ve stapler uygulanan hastalar arasında da fark bulunamamıştır. Diğer yandan Fok ve ark. (1991) 580 özofageal anastomozlu 
hastada yaptıkları çalışmalarında, manuel yapılan tek katmanlı anastomozlarda \% 5, sirküler stapler ile yapılan anastomozlarda \% 3,8 anastomoz kaçağı oranı bildirmişlerdir. Ancak anastomozu staplerle yapılan hastalarda yüksek striktür oranı bulunmuştur. Katariya ve ark. (1994) transhiyatal özofajektomi uygulanan 1353 hastada \% 15 servikal anastomoz kaçağı, \% 15 hastada anastomoz striktürü tespit etmiştir. Dewar ve ark. (1992) 169 servikal özofagogastrik anastomozlu hastada \% 17 anastomoz kaçağ 1 \% 31 anastomoz striktürü tespit etmişlerdir. Mayo kliniğinin 131 transhiyatal özofajektomi uygulanan hastada yaptığı çalışmada \% 25 servikal kaçak oranı tespit edilmiştir (Vigneswaran ve ark., 1993). Bu sonuçlara göre bu hastalarda fonksiyonel bir fayda görmek için kaçağın önlenmesi gerekmektedir. Servikal fistül genellikle 7-10 günde eksternal drenajla iyileşir. Hasta taburcu olduktan iki hafta sonra kontrole geldiğinde 46 numara ya da daha büyük Maloney buji kalibrasyon amaciyla anastomozdan geçirilir. Eğer hastanın disfajisi yoksa ve bujinin geçişine rezistans görülmüyorsa daha sonra dilatasyonlara gerek yoktur. Bujinin geçemeyeceği kadar darlık olan hastalarda daha agresif bir özofageal dilatasyon ilk etapta uygulanır. Böylece erken evrede skar dokusunun giderilmesi amaçlanır ve anastomozda sıklıkla iyileşme gözlenir. Anastomotik striktür görülen hastalarda dilatör ilerledikçe rezistans artar ve bu hastalarda daha sık dilatasyon uygulanması gerekir. $\mathrm{Bu}$ durumda hastalara 46/48 numara Fransız bujisini bir yardımc1 aracılığı ile boğazından geçirilmesi öğretilir. Bir kere dilatör ile pasaj açıklığı sağlandıktan sonra hastaya günlük ya da haftalık, daha sonra ise daha uzun aralıklarla dilatörü uygulaması söylenir. $\mathrm{Bu}$ agresif dilatasyon programıyla ilerleyen zamanda ek dilatasyonlara çoğunlukla gerek kalmaz. Çok az hasta anastomoz revizyonuna gerek duyar. Nadir olarak endoskopik steroid uygulaması yapılır (Kirsch ve ark., 1991).

\section{Fistül}

Hava yolları ile özofagus arasındaki fistül önemli bir problemdir. Genelde hava yolları kontaminasyonu ve aspirasyondan önce hastanın kliniği bozulur. Entübe hastada endotrakeal tüpün kaf basısı trakeal mukoza ve halkaları nekroze ettiğinden fistül oluşumunda önemli bir faktördür. Özellikle hastada nazogastrik sonda da varsa iki taraflı bası ile trakeoözofageal fistül riski artar. Entübe hastada trakeal aspirasyon sırasında mide içeriği veya safra tespit edilir, yüksek inspiratuar basınç altındayken trakeadan alt gastrointestinal sisteme hava kaçmasına bağlı ani ve aşırı karın distansiyonu gelişir. Mekanik ventilasyon sırasında maksimal basınçla bile hava gerginliği sağlanamamakta ve kaçak olmaktadır. Oral gıda alanlarda yutma sırasında öksürmekle mide içeriği gelir. Tanı endoskopi veya kontrastlı grafi ile konabilir. Tanıda ve fistülün lokalizasyonunun belirlenmesinde bilgisayarlı tomografi (BT) ve üç boyutlu boyun BT yardımcı olur.

Palyatif yaklaşımlarda stent kullanımı pulmoner kontaminasyonu azaltmak ve yutkunmayı korumak amaciyla kullanılır. Literatürde belirtilen spontan kapanan vakalar küçük boyutlu, düz ve servikal seviyedeki fistüllerdir. Hepsinde anastomoz geçici olarak devre dışı bırakılmış, beslenme jejunostomisi uygulanmıştır. Cerrahi olarak fistülün kapatılması tüm vakalarda göz önüne alınmalıdır. Cerrahi uygulanamayacak genel durumu bozuk hastalarda konservatif yaklaşılır, beslenme jejunostomisi ve aspirasyon gastrostomisi açılır.

Cerrahi olarak trakeal ve özofageal defektler direkt veya kas flebi, plevra veya perikard ile kapatılır. Gerekirse segmenter rezeksiyon ve anastomoz uygulanabilir. İyileşme süreci defektin büyüklüğüne, dokuların canlılığına ve kontaminasyon durumuna bağlıdır.

\section{Reflü}

Midenin yukarı çekilmesinden sonra görülen yaygın bir problemdir. Reflünün ciddiyetinin derecesi anastomoz seviyesi ile ilgilidir. Azigos veninin üzerindeki anastomozlarda reflü oranı, venin altındaki anastomozlardan daha düşüktür. Eğer anastomoz daha aşağı seviyede ise reflü ciddidir. Biz bu komplikasyonu en aza indirmek için anastomozu terminolateral şekilde yapıyor ve büyük kurvatur tarafından glob oluşturarak anastomozlarda rutin anti reflü prosedür uyguluyoruz. Az ama sık beslenme şekli, yemekler ile birlikte bol sıvı al1mi, yemeklerden sonra yatmama gibi yaklaşımlar semptomları azaltır (Şek. 1).

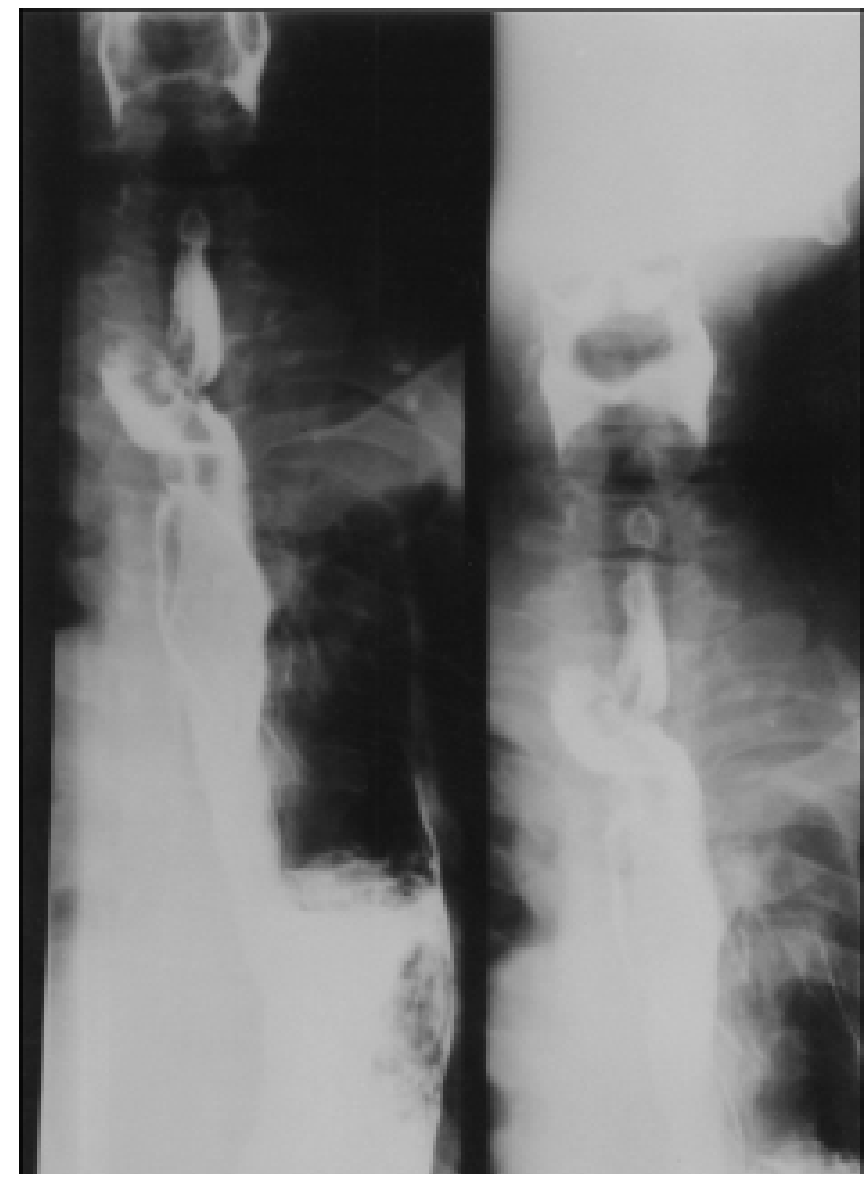

Şek. 1. Sol servikal bölgede terminolateral anastomoz ve antireflü prosedür uygulanan olgunun postoperatif baryumlu grafisi

\section{Gastrik çıkış obstrüksiyonu}

Motilite bozuklukları, gecikmiş gastrointestinal motilite ve fonksiyon yetersizliği hastaların büyük bir kısmında postoperatif dönemde karşımıza çıkabilir. Bunlar yemek sonrası şişkinlik, dumping sendromu, asit ve safra regürjitasyonu, aspirasyon ve buna bağlı pnömoni, distandü mide, dispne ve gastrik ülserlerden oluşur.

Özofajektomi ve vagotomiyi takiben gastrik drenaj prosedürü uygulaması uzun süre tartışılmıştır. Özofajektomi ve özofagogastrik anastomoz uygulanan çoğu hastada drenaj prosedürü uygulanmadığı halde gastrik çıkış obstrüksiyonunun gelişmediği gösterilmiştir (Shahian ve ark., 1972; Angorn, 1975; Huang ve ark., 1985; Holscher ve ark., 1988). Özofagus rezeksiyonu ile birlikte zorunlu vagotomiden son- 
ra mide replasmanı yaptı̆̆ımız çalışmamızda; piloroplasti veya pilorektromiye gerek olmadığını, özofagogastrostomi ameliyatını izleyen 2 ay-1 yıl sonrası dönemlerde mide motilitesinin kaybolmadığını, pilor basıncının artmadığını, mide içi basıncının midenin göğüs içi negatif basıncına rağmen azalmadığını, mide pasajının normal vakalara çok yakın olduğunu saptadık (Ökten, 1982). Bu nedenle özofagogastrostomi uygulanan hastalara rutin piloroplasti yapılması görüşüne katılmıyoruz. Duodenum ülseri veya başka nedenlerle duodenum 1. kıtasında veya pilorda oluşan deformasyon ve daralmalarda mide boşalmasının gecikmemesi için drenaj operasyonları yapılması gerekebilir. Fok ve arkadaşlarının yaptığı deneysel bir çalışmada özofagogastrostomi ile birlikte piloroplasti ve pilorektomi gibi bir drenaj işleminin gereksiz olduğu ortaya konulmuştur (Fok ve ark., 1991). Ancak ciddi gastrik çıkış, obstrüksiyonu gelişen hastada, aspirasyon pnömonisi ve yeme güçlüğüne bağlı bozulmuş beslenme gibi ciddi durumlar görülebilir. Daha da önemlisi mide gögüse taşındıktan sonra yeniden opere ederek drenaj prosedürü uygulamak zor olabilir. Bu nedenlerle bazı yazarlar özofajektomi ve özofageal rekonstrüksiyon uygulanan her hastaya gastrik drenaj prosedürü uygulanmasını önermektedir (Cheung ve ark., 1987).

\section{Diyafragmatik hiatus obstrüksiyonu ve herniasyon}

Cerrahi gereklilik nedeniyle normal anatomik yapısı bozulmuş olan diyafragmatik hiatusun genişliğii, yukarıya çekilmiş olan organın beslenmesini bozmayacak ve herniasyona izin vermeyecek şekilde olmalıdır. Herniasyonu önlemek için yukarıya çekilmiş olan doku hiatusa sütüre edilir. Herniasyon özofajektomiden günler veya yıllar sonra ortaya çıkabilir. Böyle bir herniasyon asemptomatik olabileceği gibi bulantı, kusma, sol üst kadran ağrısı gibi semptomlara da yol açabilir. Strangülasyon ve inkarserasyon riskinden dolayı herni redükte edilmelidir. Bağırsak herniasyonları transabdominal olarak tedavi edilebilir. Özofagus cerrahisini takiben çoğu komplikasyon gibi bu komplikasyon da genellikle önlenebilir. Özofageal replasman hiatustan geçirilip, anastomoz sağlandıktan sonra diyafragma krusuna yerleştirilen birkaç sıkı sütürle herniasyon önlenebilir. Mobilize edilen karaciğerin triangüler ligamanı hiatus ucuna sütüre edilerek herniasyon için bir bariyer oluşturulur (Lam ve ark., 1979; Ferguson ve ark., 1985).

\section{Silotoraks}

Özofagus ve duktus torasikusun çok yakın olması nedeniyle özofajektomiyi takiben sık görülen bir komplikasyondur. Periözofageal dokuların ligasyonu bu komplikasyonu azaltır. Aort cerrahisini takiben görülen şilotoraksa göre özofageal cerrahiden sonra görülen şilotoraks genellikle hasta tarafından iyi tolere edilemez ve mortalitesi \% 50 gibi yüksek bir orandadır (Lam ve ark., 1979; Ferguson ve ark., 1985). Çünkü kronik özofageal obstrüksiyonlu hastalar zaten nutrisyonel açıdan zayıftırlar. Bu komplikasyonu tedavi etmek için en fazla birkaç gün beklenebilir. Agresif cerrahi müdahale ve duktus torasikusun ligasyonu kesin uygulanmalıdır (Orringer ve ark., 1988).

\section{Pankreatit}

Postoperatif pankreatit Kocher manevrası veya gastrik mobilizasyona bağlı pankreatik hasar sonucu gelişebilir. Eğer hastalarda açıklanamayan ateş, respiratuar distres veya uza- mış ileus varsa pankreatitten şüphelenilmelidir. Serum amilaz ve kalsiyum seviyeleriyle tanı kesinleştirilmelidir. Standart pankreatit tedavisi uygulanır. Nadir de olsa fatal hemorajik pankreatit görülebilir (Cioffiro ark., 1976; Danforth ve Thorbjarnarson, 1976; Olsen ve Beaudoin, 1970).

\section{Dalak yaralanması}

Özofajektomi sırasında dalak hasarı özofageal replasman için midenin mobilize edilmesi sırasında görülür. Kısa gastrik damarların çekilmesinden kaçınmak ve karın açıldığında varsa dalak ve mide arasındaki adezyonların öncelikle ayrılması bu komplikasyonu önler. Rutin splenektomi yüksek mortalite ve morbidite nedeniyle önerilmemektedir (Cioffiro ve ark., 1976; Danforth ve Thorbjarnarson, 1976; Olsen ve Beaudoin, 1970).

Substernal özofageal replasmanın komplikasyonları

En önemli komplikasyon retrosternal bölgede oluşturulan hiyatal açıklık seviyesinde gelişen obstrüksiyondur. Retrosternal tüneli oluştururken açıklığı el ve ön kol retrosternal olarak girebilecek kadar dilate etmek uygun olur. Özofageal replasmanın retrosternal kompresyonu ve obstrüksiyonu, klavikulanın posterior çıkıntısı nedeniyle de olur. Bu nedenle mide veya kolonu retrosternal olarak yerleştirirken klavikulanın mediyal 1/3'ü ile ona komşu olan manubrium ve 1 . kostanın mediyal bölgesi rezeke edilerek uygun bir açıklık sağlanmış olur.

Transhiyatal özofajektomide görülen komplikasyonlar

\section{Pnömotoraks}

Transhiyatal özofajektomi uygulanan hastaların 2/3'ünde mediastinal diseksiyon sırasında bir veya her iki hemitoraksa girilebilir. Özofajektomi sonrası mide özofagus yatağına yerleştirilmeden önce plevra dikkatlice incelenmeli ve plevral açıklık olup olmadığına bakılmalıdır. Plevral açıklık varsa bir veya birden fazla tüp takılarak efektif tedavi sağlanmalıdır.

\section{Trakeal yırtılma}

Trakeal yırtılma küçük olabilir ve kolayca sütüre edilebilir. Ancak trakeaya invaze tümorün diseksiyonu sırasında ya da major bir trakeobronşial yaralanma olursa bu durum tamir edilemeyebilir. Eğer özofajektomi sırasında trakeal yırtık oluşursa anestezi tarafindan tüp kafi indirilerek distal trakeaya itilmelidir. Böylece havayolu tekrar kontrol altına alındığından yırtığın tamiri daha kontrollü şartlarda yapılabilir. Özofagusun rezeksiyonundan sonra trakeanın posteriorunun eksplorasyonu daha iyi olacağından, mümkünse transhiyatal özofajektomi tamamlandıktan sonra trakeal tamir yapılmalıdır. Eğer trakeal yırtık geniş veya karina, ana bronşları da içine alıyorsa çift lümenli endotrakeal tüp ile entübasyon uygulanmalıdır. Hasta sol yanına çevrilerek sağ posterolateral torakotomi uygulanarak 5. interkostal aralıktan sağ hemitoraksa girilir. Trakeal yırtığın yeri belirlenerek onarılır ve özofajektomi tamamlanır. Toraksı kapattıktan sonra supin pozisyona geri dönülür, geçici olarak kapatılmış olan abdominal ve servikal insizyonlar yeniden açılır. Mide posterior mediyastene çekilerek özofagogastrik anastomoz tamamlanır.

\section{Kanama}

Özofagusun beslenmesine katılan aortadan çıkan arterler özofagus duvarına ulaşmadan önce çok küçük dallara ayrı- 
lırlar. Bu damarlar transhiyatal özofajektomi sırasında zarar görür ve doğal hemostatik mekanizmalar, arteriyel vazokonstrüksiyon ile kanama kontrol altına alınır. Major kanamalar genellikle görülmez. Ortalama kan kaybı 1000 cc'den azdır. Eğer eksplorasyon sırasında diafragmatik hiyatustan aortaya veya periözofageal dokulara invazyon varsa transhiyatal teknikten uzaklaşılmalıdır.

\section{Rekürren sinir yaralanması}

Transhiyatal özofajektomi ve servikal özofagogastrostomi anastomozu sırasında rekürren sinir yaralanması nadir ancak ciddi bir komplikasyondur. Bunun sonucu olarak hırıltıll solunum, servikal disfaji, aspirasyon pnömonisi gelişebilir.

\section{Anastomoz kaçağı}

Servikal anastomoz kaçağı genellikle postoperatif 10 . günde görülen, tipik olarak az miktarda akıntı ile seyreden, nadiren fatal olabilen bir komplikasyondur. Eğer 48 saatten uzun süren, 38 derece üzeri ateş olursa kaçaktan şüphelenilmeli ve suda eriyebilen kontrast madde ile grafi çekilerek kaçak varlığı ortaya konmalıdır. Servikal kesi açılarak ve gün içersinde yapılan düzenli pansumanlarla servikal kaçak tedavi edilebilir, hastaya su içirilebilir, böylece o bölgedeki doku debride edilmiş olur. Hastanın oral beslenmesi kesilip, açılacak jejunostomiden enteral beslenme sağlanmalıdır.Postoperatif 7-10. günde gelişen kaçaklar genellikle küçük olur, pansumanlarla tedavi edilebilir. Fistül küçükse hastanın yu- muşak diyet almasına izin verilebilir. Bazen 46 numara Maloney dilatörler uygulanarak striktür ve distal obstrüksiyon önlenir, kaçak çabuk iyileşir. Genellikle servikal kaçaklar 2-3 haftada spontan olarak iyileşir.

\section{Şilotoraks}

Transhiyatal özofajektomi sonrası miktarı azalmayan gögüs tüpü drenaji olursa duktus torasikus yaralanmasına bağlı şilotorakstan şüphelenilmelidir. Hasta oral yağ alımına başlamadan tipik şilotoraks görüntüsü oluşmayacağından sadece fazla miktardaki drenaj şilotoraks için uyarıcı olabilir. Eğer gögüs tüpü drenajı her 8 saatte 200-400 cc arasındaysa ve 48 saatten sonra drenaj hala devam ediyorsa şilotoraks düşünülmelidir. Tanı için 3-6 saat boyunca jejunostomiden 30-60 cc krema verilebilir. Göğüs tüpünden gelen sıvı karakter değiştirerek süt kıvamına gelirse tanı kesinleşir. Jejunostomiden uygun beslenme protokolü ile 3-5 gün içersinde dramatik düzelme olabileceği gibi torakotomi ile hasarlı duktus torasikusun ligate edilmesi en efektif yoldur.

\section{Sempatik plevral efüzyon}

Mediyasten diseksiyonundan sonra ilk haftada sempatik plevral efüzyon gelişebilir. Bu efüzyon asemptomatiktir, çoğunlukla tedavi gerektirmez ve spontan olarak rezolüsyon olur. Bazen dispneye neden olan efüzyonlar gelişerek birçok torasentez gerektirebilir. Rekürren plevral efüzyonların şilotorakstan mutlaka ayırımı yapılmalıdır.

\section{KAYNAKLAR}

Akiyama, H., Hiyama, M.A., 1974. Simple esophageal bypass operation by the high gastric division. Surgery. 75, 674-681.

Angorn, I.B., 1975. Oesophagogastrectomy without a drainage procedure in esophageal carcinoma. Br. J. Surg. 62, 601-604.

Cheung, H.C., Siu, K.F., Wong, J., 1987. Is pyloroplasty necessary in esophageal replacement by stomach? A prospective randomized controlled trial. Surgery. 102, 19-24.

Cioffiro, W., Schein, C.J., Gliedmann, M.L., 1976. Splenic injury during abdominal surgery. Arch. Surg. 111, 167-171.

Danforth, D.N., Thorbjarnarson, B., 1976. Incidental splenectomy: A review of the literature and the New York hospital experience. Ann. Surg. 183, 124-129.

Dewar, L., Gelfand, G., Finley, R.J., Evans, K., Inculet, R., Nelems, B., 1992. Factors affecting cervical anastomotic leak and stricture formation follow esophagogastrectomy and gastric tupe interposition. Am. J. Surg. 163, 484-489.

Ferguson, M.K., Little, A.G., Skinner, D.B., 1985. Current concepts in the management of postoperative chylothorax. Ann. Thorac. Surg. 40, 542-545.

Fok, M., Ah-Chong, A.K., Cheng, S.W., Wong, J., 1991. Comparison of a single layer continuous hand sewn method and circular stapling in 580 esophageal anastomoses. Br. J. Surg. 78, 342-345.

Fok, M., Cheng, S.W., Wong, J., 1991. Pyloroplasty versus no drainage in gastric replacement of the esophagus. Am. J. Surg. 162, 447-452.

Holscher, A.H., Voit, H., Buttermann, G., Siewert, J.R., 1988. Function of the intrathoracic stomach as esophageal replacement. World J. Surg. $12,835-844$

Huang, G.J., Zhang, D.C., Zhang, D.W., 1985. A comparative study of resection of carcinoma of the esophagus with and without pyloroplasty. In: DeMeester, T.R., Skinner, D.B., eds. Esophageal disorders: Pathophysiology and therapy. New York. Raven Pres. 383.

Iannettoni, M.D., Whyte, R.I., Orringer, M.B., 1995. Catastrophic complications of the cervical esophagogastric anastomosis. J. Thorac. Cardiov. Sur. 110, 1493-1500.

Katariya, K., Harvey, J.C., Pina, E., Beattie, E.J., 1994. Complications of transhiatal esophagectomy. J. Surg. Oncal. 57, $157-163$.

Kirsch, M., Blue, M., Desai, R.K., Sivak, M.V. Jr., 1991. Intralesional steroid injections for peptic esophageal strictures. Gastrointest. Endosc. 37, 180-182.

Kron, I.L., Johnson, A.M., Morgan, R.F., 1989. Gastrotracheal fistula: A late complication after transhiatal esophagectomy. Ann. Thorac. Surg. 47, 767-768.

Lam, K.H., Lim, S.T., Wong, J., Ong, G.B., 1979. Chylothorax following resection of the oesophagus. Br. J. Surg. 66, 105-109.

Muller, J.M., Erasmi, H., Stelzner, M., Zieren, U., Pichlmaier, H., 1990. Surgical therapy of carcinoma. Br. J. Surg. 77, 845-857.

Olsen, W.R., Beaudoin, D.E., 1970. Surgical injury to the spleen. Surg. Gynecol. Obstet. 131, 57-62.

Orringer, M.B., Bluett, M., Deep, G.M., 1988. Agressive treatment of chylothorax complicating transhiatal esophagectomy without thoracotomy. Surgery. 104, 720-726.

Orringer, M., Marshall, B., Iannettoni, M.D., 2000. Eliminating the cervical esophagogastric leak with a side-to-side stapled anastomasis. J. Thorac. Cardiov. Sur. 119, 277-288.

Ökten, İ., 1982. İntratorasik yerleştirilmiş vagatomize midede mide boşalmasının incelenmesi. Ankara Tıp Bülteni. 4, 83-87.

Postlethwait, R., 1983. Complications and deaths after operations for esophageal carcinoma. J. Thorac. Cardiov. Sur. 85, 827-831. 
Shahian, D., Neptune, W., Ellis, F.H., Watkins, E. Jr., 1986. Transthoracic versus extrathoracic esophagectomy: Mortality, morbitidy and longterm survival. Ann. Thorac. Surg. 41, 237-246.

Shapiro, S., Hamlin, D., Morgenstern, L., 1972. The fate of the pylorus in esophagogastrectomy. Surg. Gynecol. Obstet. 135, $216-218$.

Vigneswaran, W.T., Trastek, V.F., Pairolero, P.C., Deschamps, C., Daly, R.C., Allen, M.S., 1993. Transhiatal esophagectomy for carcinoma of the esophagus. Ann. Thorac. Surg. 56, 836. 